\title{
ALDOSTERONE SECRETION AND PRIMARY AND MALIGNANT HYPERTENSION *
}

\author{
By JOHN H. LARAGH, STANLEY ULICK, VLODZIMIERZ JANUSZEWICZ, \\ QUENTIN B. DEMING, WILLIAM G. KELLY AND \\ SEYMOUR LIEBERMAN \\ (From the Departments of Medicine, of Obstetrics and Gynecology and of Biochemistry, College \\ of Physicians and Surgeons, Colimbia University, The Presbyterian Hospital, \\ and the Columbia University Research Service, Goldwater \\ Memorial Hospital, New York N. Y.)
}

(Submitted for publication November 9, 1959; accepted March 24, 1960)

After the synthesis of desoxycorticosterone (DOC), it became apparent that this corticosteroid, the physiological effects of which are concerned primarily with sodium and potassium metabolism, can produce a state of hypertension both in animals and in man $(1,2)$. The induced hypertension is dependent upon the administration of adequate amounts of dietary sodium, whereas the hypertensive state, produced by administration of glucocorticoids such as cortisone, differs in that it is independent of the dietary sodium content (3).

More recently, following the chemical and biological characterization of the mineralocorticoid hormone, aldosterone (4), a disease state associated with primary hypersecretion of this hormone has been described in man (5). Aldosterone produces effects on sodium and potassium metabolism similar to those of desoxycorticosterone, and the clinical syndrome of primary aldosteronism resembles the disease state produced by chronic administration of DOC to dogs (6). Arterial hypertension has been a consistent finding in patients with primary hyperaldosteronism.

A number of other observations have suggested a relationship between the dietary sodium intake and the blood pressure level of patients with primary (benign essential) hypertension. The beneficial effects of sodium deprivation, and of various natriuretic agents in certain patients with hypertension, is well known. In addition, other studies have suggested that abnormalities of intracellular sodium and potassium content may occur in patients with arterial hypertension (7). Genest, Koiw, Nowaczynski and Lebouef (8) have re-

* This work was supported by a grant from the United States Public Health Service (H-1275), the Fleitas Fund, and by Mr. Daniel G. Arnstein. ported that the urinary excretion of aldosterone was significantly increased in 55 per cent of their patients with hypertension of diverse etiologies. The increased levels of urinary aldosterone were not correlated with any abnormality of sodium or potassium metabolism, nor did the increased values appear to be specifically associated with any particular type of hypertensive disease.

It has been recognized that the measurement of urinary excretion of unchanged hormone may not accurately reflect significant changes in adrenal secretion of aldosterone. During the past several years a method has been devised which provides an estimate of the amount of aldosterone which is actually produced by the adrenal glands (9). The technique involves the injection of a trace amount of tritiated aldosterone and the determination of the specific activity of a urinary metabolite of aldosterone in the subsequent 24 hour urine. The difference between the specific activity of the injected hormone and that of the urinary metabolite is considered to be a measure of the endogenous production of aldosterone and, as such, permits the estimation of the daily secretion rate. In the present report, this technique has been applied to the study of patients with arterial hypertension. In the course of these studies an effort has been made to correlate abnormalities in aldosterone secretion with abnormalities in sodium and potassium metabolism and, when possible, with changes in the morbid anatomy of the adrenal gland itself. The results have been compared with values obtained from normal subjects and from patients with known primary aldosteronism.

\section{METHODS AND MATERIALS}

Patient selection. All of the patients studied were hospitalized. A complete history and physical examina- 
tion, routine laboratory tests, plasma and urinary electrolytes, intravenous pyelography and measurement of catecholamine excretion were obtained in all patients. None of the patients included in the group had evidence of congestive heart failure. Frequently, the dietary intake of sodium was stabilized by means of a constant diet prepared by the metabolic ward kitchen, and serial control observations were then made while the patients were on the metabolic ward. These detailed studies will be reported at a later date. Some of the patients were hospitalized at the Goldwater Memorial Hospital, Columbia Division. All of the latter group had been in the hospital for considerable periods of time, and in several instances, daily blood pressure measurements for several years, as well as frequent determinations of plasma and urinary electrolytes, were available.

Classification of hypertensive patients. After efforts to exclude primary renal or adrenal disease the remaining hypertensive group selected for study was subdivided. The patients with elevated blood pressures but with no evidence of renal insufficiency or of arteritis were classified as "primary hypertension" (often called, "benign essential" hypertension). The patients with high blood pressure and evidence of renal or retinal complications were classified as "advanced hypertension" or "primary hypertension with complications." The criterion for renal complications was the presence of either proteinuria or a blood urea nitrogen greater than $30 \mathrm{mg}$ per $100 \mathrm{ml}$ or both. Retinal complications refer to the presence of retinal hemorrhages (Grade III retinopathy according to the standard classification). Patients with unequivocal papilledema were classified as the accelerated form or "malignant" hypertension. It was recognized that this classification, although useful, was arbitrary, and that diverse etiologies could exist within these categories. For comparative purposes a group of patients with primary aldosteronism was also studied. Diagnosis in these patients was made on the basis of 1) hypokalemic alkalosis, 2) hypertension, and 3) the finding of an adrenal tumor at operation or at postmortem.

The metabolic ward techniques and the methods used for measurement of plasma and urinary electrolytes have been reported previously (10). Blood pressures were measured with a standard cuff-type mercury manometer.

The $d$-aldosterone employed in this study was tritiated by the Wilzbach procedure (11) in the laboratories of the New England Nuclear Corporation. It was then purified to constant specific activity by paper chromatography. The paper used in the final chromatogram was washed in a Soxhlet apparatus with ethanol for 1 week prior to use. The aldosterone was eluted from this chromatogram with ethanol, and the eluate was filtered through a fine sintered glass filter. This solution was diluted with sterile water to make a 10 per cent ethanol solution for intravenous injection.

Urine was collected for 24 hours after the injection of tritiated aldosterone and hydrolyzed with $\beta$-glucuronidase at $\mathrm{pH} 5.0$ for 3 days at $37^{\circ} \mathrm{C}$. An extract of the hydrolyzed urine was prepared with ethyl acetate. The tetrahydro-metabolite of aldosterone was isolated from the extract by paper chromatography, and acetylated with $\mathrm{C}^{\mathbf{1 4}}$-labeled acetic anhydride of known specific activity. The triacetate of the metabolite then was chromatographed first on paper and next on a partition column. The $\mathrm{H}^{3} / \mathrm{C}^{14}$ ratios in the fractions from the partition column were determined by liquid scintillation counting with a Packard Tri-Carb scintillation counter using the discriminator ratio method of Okita, Kabara, Richardson and LeRoy (12). Constancy of the ratios in the area of the tritium peak is indicative of radiochemical purity. The aldosterone secretion rate in micrograms per day can be shown to equal

counts per minute of aldosterone injected

specific activity of the metabolite in 24 hour urine (counts per minute per microgram)

$\mathrm{H}^{3} / \mathrm{C}^{14}$ times the specific activity of the $\mathrm{C}^{14}$-acetic anhydride equals the specific activity of the aldosterone metabolite. It is evident that the $\mathrm{H}^{3} / \mathrm{C}^{14}$ ratio is a measure of the specific activity of the metabolite. This technique has been previously outlined (9) and will be described in detail in a manuscript which is in preparation.

Plan of study. Because aldosterone secretion varies considerably with the dietary sodium intake (9), an effort was made to stabilize the dietary sodium content for at least 5 days prior to study. With this precaution and in the absence of any demonstrable renal or adrenal insufficiency it was felt that the 24 hour urinary sodium level represented a reasonably good index of sodium metabolism at the time the aldosterone production was measured. In 17 subjects in whom a metabolic balance was not feasible the urinary sodium content was checked for several days before and after the administration of aldosterone. If these values were not grossly reduced (below $20 \mathrm{mEq}$ per day), if the patients exhibited no other signs of fluid retention, and if there was no history of recent sodium deprivation, a state of sodium retention was considered unlikely. However, in most (20 of 27) of these patients a complete metabolic balance was carried out. In no instance did the patients receive diuretic agents for at least 3 weeks prior to study.

\section{RESULTS}

The results are summarized in Table $\mathrm{I}$ and in Figure 1.

Normal subjects. In Figure 1 the results obtained in eight normal subjects on unselected diets are presented graphically. The aldosterone secretion rate ranged from 150 to $330 \mu \mathrm{g}$ per day in these eight subjects. The corresponding 24 hour urinary sodium outputs ranged from 82 to 254 $\mathrm{mEq}$ per day. With the same techniques employed as in the present study, it has been shown previously that normal subjects studied increased their aldosterone secretory rate to about 1,000 
$\mu \mathrm{g}$ per day in response to sodium deprivation, and that the feeding of large amounts of sodium reduced the rate to as low as $50 \mu \mathrm{g}$ per day (9).

Primary hypertension. In eight subjects with primary hypertension the adrenal secretory rate of aldosterone ranged from 180 to $330 \mu \mathrm{g}$ per day. These values are within the normal range. In this group, there were no abnormalities in either plasma or urinary electrolytes suggestive of aldosteronism. All but one of these subjects (no. 2) were without medication. Prior to the study, two of the subjects (nos. 2 and 7 ) had had at least one cerebral thrombosis with recovery. There was no evidence of renal failure nor of any other complications in the subjects included in this group.
Unilateral renal disease. Patients 9 and 10 manifested the clinical picture of advanced hypertension which was presumably the result of unilateral renal disease. In Patient 9 the diagnosis had been established by demonstration of anomalous right renal arteries on aortography and was confirmed by surgical removal of the abnormal right kidney and a subsequent sharp fall in blood pressure which has now been sustained for a year. A filling defect in one kidney was clearly demonstrated by pyelography in Patient 10 three years after the onset of severe hypertension. This patient was considered a poor surgical risk, and nephrectomy was not performed. Aldosterone secretory rates of Patients 9 and 10 were within the

TABLE I

Aldosterone secretory rates and related clinical and morphological findings in hypertensive patients

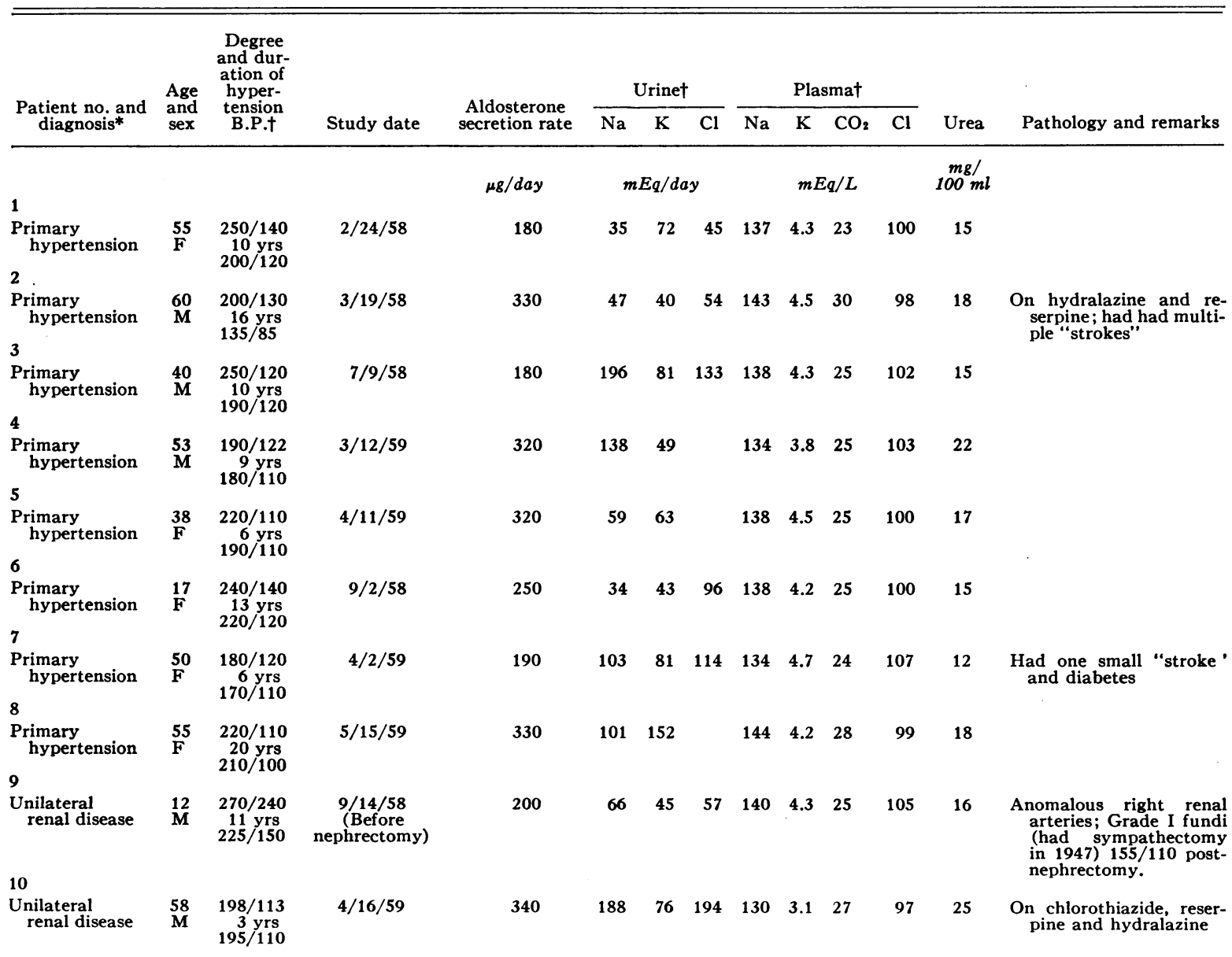

* Patient 12 was studied through the courtesy of Dr. Robert D. Gittler; Patient 13, courtesy of Dr. Marion Isaacs of the Veterans Administration Hospital, First Avenue at 24th Street; Patient 14, courtesy of Dr. H. Chase of Brooklyn Jewish Hospital. Patients 20 and 26 were studied through the kind cooperation of Dr. Milford Fulop of the Albert Einstein College of Medicine. Patient 27 has been previously reported in detail
throun

t At time of study. 
TABLE I-Continued

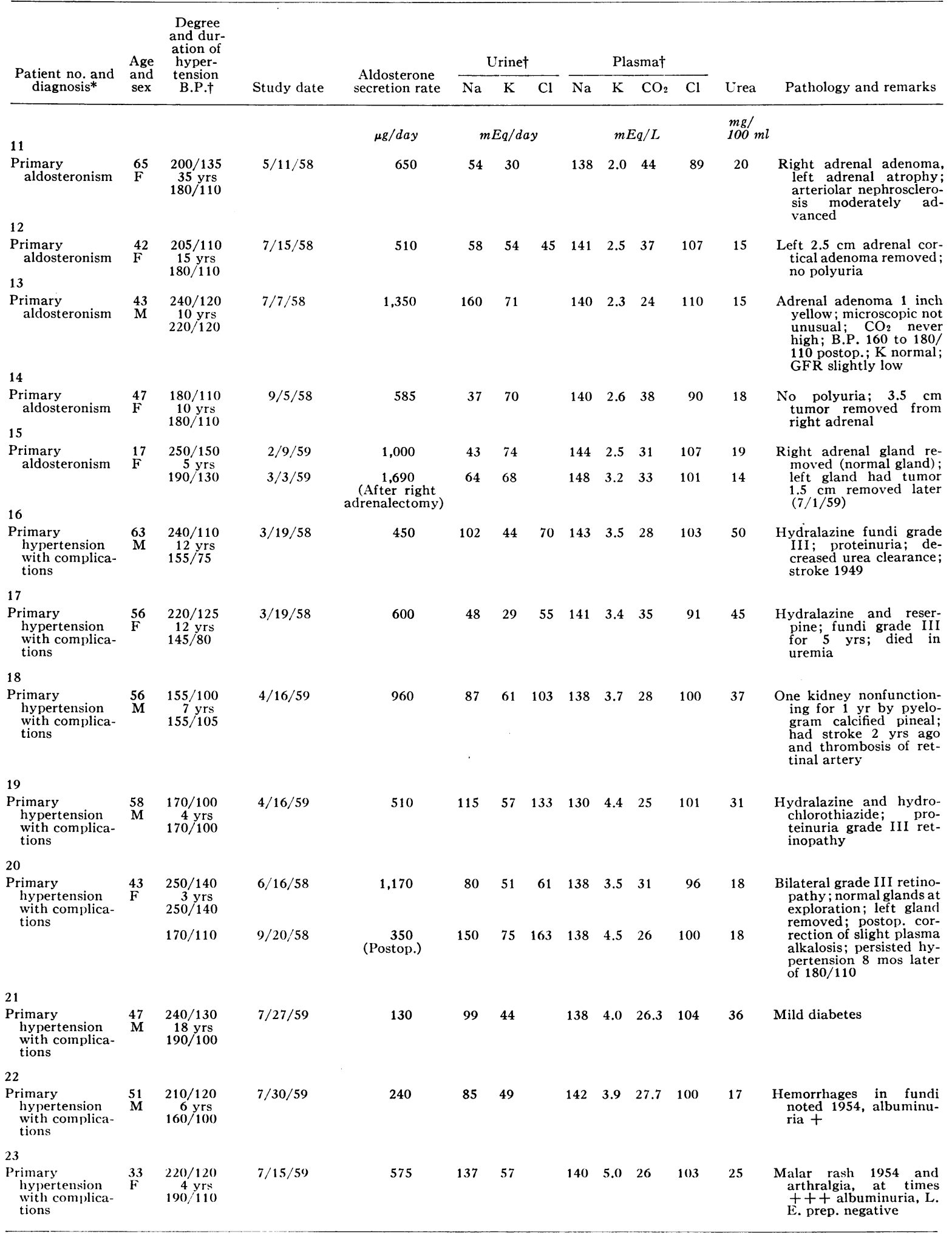


TABLE I-Continued

\begin{tabular}{|c|c|c|c|c|c|c|c|c|c|c|c|c|c|}
\hline \multirow{2}{*}{$\begin{array}{l}\text { Patient no. and } \\
\text { diagnosis* }\end{array}$} & \multirow{2}{*}{$\begin{array}{l}\text { Age } \\
\text { and } \\
\text { sex }\end{array}$} & \multirow{2}{*}{$\begin{array}{l}\text { Degree } \\
\text { and dur- } \\
\text { ation of } \\
\text { hyper- } \\
\text { tension } \\
\text { B.P.† }\end{array}$} & \multirow[b]{2}{*}{ Study date } & \multirow{2}{*}{$\begin{array}{c}\text { Aldosterone } \\
\text { secretion rate }\end{array}$} & \multicolumn{3}{|c|}{ Irinet } & \multicolumn{4}{|c|}{ Plasmał } & \multirow[b]{2}{*}{ Urea } & \multirow[b]{2}{*}{ Pathology and remarks } \\
\hline & & & & & $\mathrm{Na}$ & $\mathbf{K}$ & $\mathrm{Cl}$ & $\mathrm{Na}$ & $\mathrm{K}$ & $\mathrm{CO}_{2}$ & $\mathrm{Cl}$ & & \\
\hline 24 & & & & $\mu g / d a y$ & \multicolumn{3}{|c|}{$m E q / d a y$} & & \multicolumn{2}{|c|}{$m E q / L$} & & $\stackrel{m g /}{100} \mathrm{ml}$ & \\
\hline $\begin{array}{l}\text { Malignant } \\
\text { hypertension } \\
25\end{array}$ & $\mathbf{F}$ & $\begin{array}{c}240 / 149 \\
12 \text { yrs } \\
160 / 110\end{array}$ & $9 / 13 / 58$ & 520 & 130 & 67 & 122 & 138 & 3.6 & 30 & 99 & 53 & $\begin{array}{l}\text { Mecamylamine and re- } \\
\text { serpine }\end{array}$ \\
\hline $\begin{array}{l}\text { Malignant } \\
\text { hypertension }\end{array}$ & $\begin{array}{l}56 \\
\mathrm{M}\end{array}$ & $\begin{array}{l}250 / 150 \\
20 \text { yrs }\end{array}$ & $4 / 28 / 58$ & 600 & 69 & 60 & 40 & 135 & 3.5 & 35 & 92 & 27 & $\begin{array}{l}\text { Not helped by bilateral } \\
\text { adrenalectomy in } 2\end{array}$ \\
\hline " & & $240 / 150$ & $6 / 9 / 58$ & $\begin{array}{c}760 \\
\text { (Postop. } \\
\text { first stage) }\end{array}$ & 36 & 62 & 30 & 138 & 3.2 & 35 & 92 & 41 & $\begin{array}{l}\text { stages; terminal ure- } \\
\text { mia; adrenal glands } \\
\text { showed nodular hyper- } \\
\text { plasia but normal } \\
\text { weight, proteinuria + + }\end{array}$ \\
\hline $\begin{array}{l}\text { Malignant } \\
\text { hy pertension } \\
27\end{array}$ & $\stackrel{46}{F}$ & $\begin{array}{l}250 / 150 \\
9 \text { yrs } \\
215 / 130\end{array}$ & $3 / 19 / 58$ & 800 & 26 & 56 & 42 & 133 & 3.5 & 30 & 92 & 35 & Reserpine \\
\hline $\begin{array}{l}\text { Malignant } \\
\text { hypertension } \\
28\end{array}$ & $\begin{array}{l}\mathbf{5 5} \\
\mathbf{M}\end{array}$ & $\begin{array}{r}240 / 160 \\
2 \mathrm{mos} \\
250 / 150\end{array}$ & $4 / 21 / 58$ & 1,020 & 47 & 66 & & 139 & 3.7 & 28 & 99 & 58 & $\begin{array}{l}\text { Bilateral adrenal cortical } \\
\text { hyperplasia at post- } \\
\text { mortem }\end{array}$ \\
\hline $\begin{array}{l}\text { Malignant } \\
\text { hypertension }\end{array}$ & $\begin{array}{l}59 \\
\mathbf{M}\end{array}$ & $\begin{array}{c}170 / 100 \\
4 \text { yrs } \\
165 / 100\end{array}$ & $4 / 16 / 59$ & 600 & 35 & 45 & 40 & 131 & 3.9 & 25 & 105 & 30 & $\begin{array}{l}\text { Hydralazine and reser- } \\
\text { pine; was alkalotic at } \\
\text { times; was severely ma- } \\
\text { lignant prior to drug } \\
\text { therapy (4 yrs ago) }\end{array}$ \\
\hline $\begin{array}{l}\text { Malignant } \\
\text { hypertension } \\
30\end{array}$ & $\begin{array}{l}48 \\
M\end{array}$ & $\begin{array}{l}280 / 160 \\
3 \text { yrs } \\
230 / 130\end{array}$ & $4 / 21 / 59$ & 860 & 53 & 79 & 72 & 135 & 3.7 & 26 & 95 & 71 & $\begin{array}{l}\text { Adrenal glands over- } \\
\text { weight and hyperplastic } \\
\text { at postmortem }\end{array}$ \\
\hline $\begin{array}{l}\text { Malignant } \\
\text { hypertension }\end{array}$ & $\begin{array}{l}53 \\
\mathbf{M}\end{array}$ & $\begin{array}{c}220 / 130 \\
4 \text { yrs } \\
160 / 110\end{array}$ & $5 / 15 / 59$ & 1,220 & 101 & 54 & 55 & 132 & 3.6 & 30 & 92 & 37 & $\begin{array}{c}\text { Hydralazine } \\
\text { camylamine }\end{array}$ and me- \\
\hline $\begin{array}{l}\text { Malignant } \\
\text { hypertension } \\
32\end{array}$ & $\frac{42}{F}$ & $\begin{array}{l}250 / 160 \\
5 \text { yrs } \\
240 / 150\end{array}$ & $\begin{array}{r}3 / 21 / 59 \\
3 / 26 / 59 \\
4 / 8 / 59\end{array}$ & $\begin{array}{l}2,180 \\
1,650 \\
1,450\end{array}$ & $\begin{array}{c}43 \\
8.5 \\
122\end{array}$ & $\begin{array}{l}66 \\
50 \\
55\end{array}$ & & $\begin{array}{l}140 \\
138 \\
133\end{array}$ & $\begin{array}{l}4.1 \\
4.4 \\
2.9\end{array}$ & $\begin{array}{l}27 \\
31 \\
27\end{array}$ & $\begin{array}{r}95 \\
99 \\
100\end{array}$ & $\begin{array}{l}45 \\
54 \\
40\end{array}$ & $\begin{array}{l}\text { Adrenal glands normal } \\
\text { weight; ; possibly hyper- } \\
\text { plasia }\end{array}$ \\
\hline $\begin{array}{l}\text { Malignant } \\
\text { hypertension } \\
33\end{array}$ & $\frac{44}{F}$ & $\begin{array}{l}250 / 150 \\
15 \text { yrs } \\
200 / 100\end{array}$ & $10 / 8 / 58$ & 2,730 & 51 & 113 & 91 & 141 & 3.2 & 28 & 101 & 47 & $\begin{array}{l}\text { Microscopic adrenal hy- } \\
\text { perplasia (nodular) }\end{array}$ \\
\hline $\begin{array}{l}\text { Malignant } \\
\text { hypertension }\end{array}$ & $\frac{23}{F}$ & $\begin{array}{c}260 / 150 \\
5 \text { yrs } \\
240 / 150\end{array}$ & $9 / 28 / 58$ & 1,600 & 67 & 54 & 75 & 125 & 3.8 & 32 & 76 & 81 & $\begin{array}{l}\text { Had } \\
\text { 8/56; adrenalsectomy } \\
\text { mal" at operation }\end{array}$ \\
\hline $\begin{array}{l}\text { Malignant } \\
\text { hypertension }\end{array}$ & ${ }_{\mathrm{F}}^{7}$ & $\begin{array}{l}300 / 150 \\
5 \text { yrs } \\
250 / 140\end{array}$ & $8 / 30 / 58$ & 740 & 36 & 20 & 33 & 133 & 3.1 & 28 & 93 & 15 & Normal aortogram \\
\hline $\begin{array}{l}\text { Malignant } \\
\text { hypertension }\end{array}$ & F & $\begin{array}{c}260 / 140 \\
4 \text { yrs } \\
230 / 130\end{array}$ & $9 / 18 / 58$ & 190 & 141 & 47 & 92 & 135 & 4.2 & 22 & 102 & 20 & $\begin{array}{l}\text { Hydralazine, had sym- } \\
\text { pathectomy } 1 \text { yr prior } \\
\text { to test with consider- } \\
\text { able benefit }\end{array}$ \\
\hline $\begin{array}{l}\text { Malignant } \\
\text { hypertension } \\
37\end{array}$ & $\begin{array}{l}53 \\
\mathbf{M}\end{array}$ & $\begin{array}{c}250 / 149 \\
14 \text { yrs } \\
240 / 140\end{array}$ & $6 / 30 / 59$ & 1,500 & 25 & 35 & & 140 & 3.2 & 32 & 101 & 22 & $\begin{array}{c}\text { Polyuria } 2 \text { to } 3 \mathrm{~L} \text { for } \\
12 \mathrm{yrs}\end{array}$ \\
\hline $\begin{array}{l}\text { Malignant } \\
\text { hypertension }\end{array}$ & $\frac{46}{F}$ & $\begin{array}{l}250 / 160 \\
12 \text { yrs } \\
220 / 160\end{array}$ & $7 / 3 / 59$ & 10,000 & 42 & 76 & & 126 & 3.9 & 27 & 79 & 78 & $\begin{array}{l}\text { Plasma bicarbonate as } \\
\text { high as } 40 \mathrm{mEq} / \mathrm{L}, \mathrm{K} \text { as } \\
\text { low as } 2.1 ; \text { glands } \\
\text { grossly normal at post } \\
\text { but hyperplastic micro- } \\
\text { scopically }\end{array}$ \\
\hline $\begin{array}{l}\text { Malignant } \\
\text { hypertension }\end{array}$ & $\stackrel{27}{\mathbf{M}}$ & $\begin{array}{r}240 / 140 \\
6 \text { mos } \\
240 / 140\end{array}$ & $7 / 25 / 59$ & 700 & 94 & 101 & & 135 & 3.5 & 30 & 89 & 25 & $\begin{array}{l}\text { Many retinal hemor- } \\
\text { rhages; }++ \text { albuminu- } \\
\text { ria }\end{array}$ \\
\hline
\end{tabular}

normal range, 200 and $340 \mu \mathrm{g}$ per day, respectively.

Primary aldosteronism. Patients 11-15 represent examples of proven primary aldosteronism (Conn's syndrome). In these patients the adrenal secretory rate was significantly increased above normal values, ranging from 510 to $1,690 \mu \mathrm{g}$ per day. These elevated aldosterone values were found in the face of relatively high values for urinary sodium excretion. All of these patients ex- 


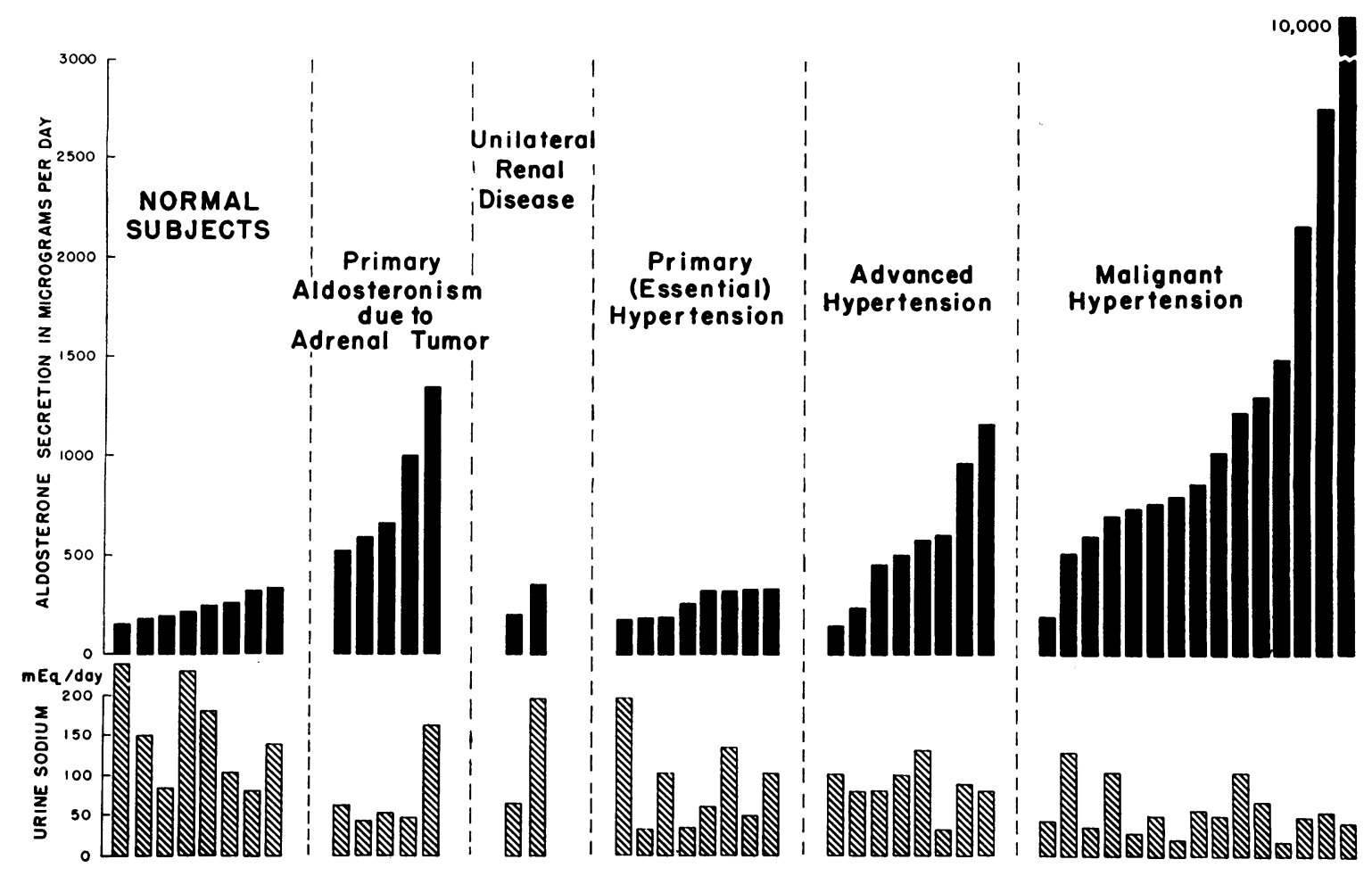

Fig. 1. Adrenal secretion rates of aldosterone (in micrograms per 24 hours) for 8 NORMAL SUbJeCts, 8 PATIENTS WITH PRIMARY HYPERTENSION, 8 PATIENTS WITH PRIMARY HYPERTENSION With COMPLICATIONS ("ADVANCED” HYPERTENSION), AND 15 PATIENTS WITH MALignANT HYPERTENSION. For comparative purposes 2 patients with unilateral renal disease and 5 patients with primary aldosteronism are presented. The urinary sodium content of the corresponding 24 hour urine collection is also shown. There is no evident hypersecretion of aldosterone in primary hypertension. In malignant hypertension marked hypersecretion of aldosterone was found and the values were often higher than those encountered in patients with primary aldosteronism. The patients with malignant hypertension resembled those with primary aldosteronism in that the hypersecretion was not associated with grossly reduced sodium excretion.

hibited hypokalemia and all but one had an elevated plasma bicarbonate level. All of these patients had adrenal adenomas. In Patient 11 the tumor was found at autopsy after a negative laparotomy. In Patients $12-15$ the symptomatology was relieved by surgical removal of an adrenal adenoma. Patient 15, a girl, aged 17, exhibited severe hypertension with papilledema. This patient was improved after a two-stage total adrenalectomy. An adenoma of the right adrenal gland was found, but all of the adrenal tissue appeared hyperplastic on microscopic study. The significance of the adenoma is thus questionable. Precise classification of this patient is, therefore, difficult, since, as will be seen, she could also have been classified as malignant hypertension with adrenal hyperplasia.

Primary hypertension with complications ( $\mathrm{Pa}-$ tients 16-23). The patients included in this group had had their hypertensive disease for periods of from 3 to 18 years. Three of these eight patients were on antihypertensive medications as indicated (Table I) at the time of the study. Five of the patients included in this group had significant nitrogen retention (nos. 16-19 and 21) and seven had retinal hemorrhages (nos. 16, 17, 19-23). The aldosterone secretion rates ranged from 130 to $1,170 \mu \mathrm{g}$ per day in these patients. In five of these eight the values were above $500 \mu \mathrm{g}$ per day and appeared significantly elevated above normal. As in the patients with primary aldosteronism, the increased aldosterone production was observed in the presence of relatively high urine sodium levels (Figure 1 ). The plasma bicarbonate levels were $28 \mathrm{mEq}$ per $\mathrm{L}$ or higher in four of these patients, and in all but one plasma potassium levels 
were less than $4 \mathrm{mEq}$ per $\mathrm{L}$. With one exception (Patient 19) the increased aldosterone secretory rates were found in the patients with relatively high plasma bicarbonate levels. In five of the eight patients in this group the blood urea nitrogen exceeded $30 \mathrm{mg}$ per $100 \mathrm{ml}$. However, the elevated aldosterone production did not appear to be constantly associated with this nitrogen retention.

Patient 20 was subjected to laparotomy, and, when no tumor was found, a left adrenalectomy was carried out. The gland was grossly normal but microscopically revealed some nodularity and focal hyperplasia. It is of interest that following this procedure there was a sustained (9 months' observation) fall in blood pressure to levels of $170 / 110$ and complete clearing of retinal hemorrhages. After the unilateral adrenalectomy the aldosterone secretion rate was also markedly reduced from $1,170 \mu \mathrm{g}$ per day to a value within the normal range of $352 \mu \mathrm{g}$ per day. The sequence of events raised the possibility that hypersecretion of aldosterone might have been a factor in accelerating this patient's hypertensive disease.

Malignant hypertension (Patients 24-38). Fifteen patients with malignant hypertension characterized by papilledema were studied. The known duration of the hypertension in this group ranged from 2 months to 20 years. However, the duration of the papilledema in these cases is difficult to determine. In most instances, it appeared to be a relatively recent development as the disease state progressed from the benign to the so-called accelerated form.

The adrenal secretion rate of aldosterone in these patients with malignant hypertension ranged from 190 to $10,000 \mu \mathrm{g}$ per day. All of the values were markedly elevated above normal except for that of Patient 35. The range for the remaining 14 patients was from 520 to $10,000 \mu \mathrm{g}$ per day. Patient 35 differs perhaps from the rest of the group in that at the time of study she was considerably improved following sympathectomy. Furthermore, more recently, papilledema has subsided, and this patient appears to be free of the "malignant" state. Another sympathectomized patient in the group (no. 33) exhibited an elevated secretion rate, but in this patient the operation was not associated with clinical improvement.

In this group of patients with malignant hy- pertension, significant nitrogen retention was present in 9 of the 15 (blood urea nitrogen over 30 $\mathrm{mg}$ per $100 \mathrm{ml}$ ). Despite this evidence of renal insufficiency, in 6 of the 15 the plasma bicarbonate values were $30 \mathrm{mEq}$ per $\mathrm{L}$ or higher, and in 9 of the 15 the values were $28 \mathrm{mEq}$ per $\mathrm{L}$ or higher. These values appear particularly impressive because they were often encountered in the presence of nitrogen retention, which is characteristically associated with retention of fixed anions and an associated reduction in the plasma bicarbonate concentration. Perhaps even more striking was the fact that in 13 of the 15 patients in this group the plasma potassium values were found to be less than $4.0 \mathrm{mEq}$ per $\mathrm{L}$, and in 10 of 15 were less than $3.8 \mathrm{mEq}$ per L. Again, in the face of renal insufficiency, the tendency to hypokalemic alkalosis in these patients is noteworthy and perhaps affords supporting evidence suggesting the presence of hyperaldosteronism.

The markedly increased aldosterone secretion in this group of patients was found, as in the patients with Conn's syndrome, to occur in the presence of relatively high urinary sodium levels and was, therefore, clearly not associated with a state of progressive sodium retention. Although the urinary $\mathrm{Na}$ levels were never grossly reduced (range, 25 to $113 \mathrm{mEq}$ per day), they were somewhat lower than those in the other patients (see Figure 1). There was no evidence of significant positive sodium balance in any of these patients and the lowered excretions were the result of lower intake. The increased aldosterone secretion appears to be far in excess of what one would normally find in association with such levels of urinary sodium excretion.

Relation of aldosterone secretion to blood pressure level. No correlation was evident between the degree of elevation of blood pressure and the degree of elevation in the aldosterone secretory rate in this series of patients. Many of the patients with primary hypertension manifested blood pressure elevations which were as high or higher than those observed in the patients with primary hypertension with complications, or in the patients with malignant hypertension.

Relation of aldosterone secretion rate to renal insufficiency. The patients with advanced or with malignant hypertension often exhibited significant nitrogen retention (13 of 23 with blood urea ni- 
trogen above $30 \mathrm{mg}$ per $100 \mathrm{ml}$ ). Yet, it is difficult to relate the increased aldosterone secretion specifically to this renal failure since a number of the patients ( 7 of 23 ) had elevated aldosterone secretion rates with a normal blood urea nitrogen.

It has been shown that patients with sodiumlosing renal disease may excrete large amounts of aldosterone. Presumably this is a secondary mechanism in an attempt to conserve sodium. Also, these patients may continue to excrete increased amounts of aldosterone long after sodium repletion, a phenomenon which has been termed "secondary primary aldosteronism" (13). It is conceivable that certain of the patients reported here had antecedent or subtle forms of sodiumlosing renal insufficiency, but, insofar as is possible, metabolic balance studies appear to have excluded this possibility at the time of the study in Patients 11-15, 20, 21, 23-28, 31, 34 and 35. These patients all had urinary sodium values of less than $10 \mathrm{mEq}$ per day after dietary deprivation. Patient 13 with primary aldosteronism and Patient 32 with malignant hypertension, manifested slight impairment of renal sodium conservation on low sodium intakes (urine sodium did not fall below $20 \mathrm{mEq}$ per day). Yet, even in these two patients, there was no evidence that the impairment of renal function had preceded the hypersecretion of aldosterone. Therefore, while it is theoretically possible that impaired renal sodium conservation could have preceded and provoked secondary hypersecretion of aldosterone in these hypertensive subjects, the available data do not establish that this was the sequence of events.

It is important to emphasize that, conceivably, as a consequence of severe renal disease the method as employed might yield an apparently high secretory rate in the absence of true hypersecretion of aldosterone. A basic requirement which must be fulfilled, if the isotope dilution technique used in this study is to measure the true secretion rate, is that the reactions involved in the conversion of radioactive hormone to radioactive metabolite and also in excretion of the radioactive metabolite into the urine must have gone to completion within the period during which the urine is collected. In other words, regardless of the other metabolites to which the injected labeled hormone may be converted, all of the isotopically labeled tetrahydrometabolite which is to be formed must have been formed and excreted within the collection period. If additional amounts of radioactive metabolite were to be excreted into subsequent urine collections, then the conditions necessary for determination of the secretion rate by isotope dilution would not exist and the value of the secretory rate derived from such an incomplete collection would be artificially high.

It has already been shown (14) that the fraction of radioactivity originating from injected $\mathrm{C}^{14}$ cortisol that appears in urine and, to a much lesser extent, the rate at which it appears in the urine, are related to the clearance of creatinine. Normal individuals with clearances of about 125 ml per minute excreted about 80 per cent of $\mathrm{C}^{14}$ in the first day's urine, whereas patients with kidney disease and creatinine clearances of 42 to 55 $\mathrm{ml}$ per minute excreted about 50 per cent in the first day, and patients with creatinine clearances of 5 to $9 \mathrm{ml}$ per minute excreted only about 3 per cent in the first 24 hours. Perhaps more importantly, in all of the subjects, very little additional radioactivity appeared on the second and third days.

The condition set forth above does not require that a certain percentage of injected radioactivity must appear in the urine. If the assumption is made that the injected labeled molecules have the same fate as the endogenously produced hormone, then if only a small fraction of injected hormone is converted to radioactive metabolite, a similar small fraction of the endogenous hormone undergoes the same fate. It is only necessary that the collection period be long enough to permit complete formation and then complete excretion of all the radioactive metabolite which is to be excreted.

Analysis of the data presented in Table II reveals no consistent relationship between the blood urea nitrogen and the aldosterone secretion rate. In Table II seven patients with good renal function (three normal subjects and four subjects with benign hypertension) are compared with seven patients with nitrogen retention. The patients with elevated blood urea values, as a group, excreted less of the injected hormone as the urinary tetrahydrometabolite than did the patients with normal renal function (average of 6.1 compared to 12 per cent). There is overlap in the two 
TABLE II

Relationship of blood urea nitrogen concentration to excretion of labeled aldosterone

\begin{tabular}{|c|c|c|c|c|}
\hline Patient & Diagnosis & BUN* & $\begin{array}{l}\text { Per cent of in- } \\
\text { jected counts } \\
\text { released by } \\
\text { glucuronidase } \\
\text { hydrolysis ( } 24 \\
\text { hour urine) }\end{array}$ & $\begin{array}{l}\text { Aldosterone } \\
\text { secretion rate }\end{array}$ \\
\hline $\begin{array}{l}\mathrm{B} \\
\mathrm{F}\end{array}$ & $\begin{array}{l}\text { Normal } \\
\text { Normal } \\
\text { Normal }\end{array}$ & $\begin{array}{c}m g / 100 m l \\
16 \\
18 \\
15\end{array}$ & $\begin{array}{r}14.3 \\
7.9 \\
8.7\end{array}$ & $\begin{array}{c}\mu g / 24 \text { hrs } \\
334 \\
170 \\
255\end{array}$ \\
\hline $\begin{array}{l}4 \\
6 \\
7 \\
8\end{array}$ & $\begin{array}{l}\text { Primary hypertension } \\
\text { Primary hypertension } \\
\text { Primary hypertension } \\
\text { Primary hypertension }\end{array}$ & $\begin{array}{l}22 \\
15 \\
12 \\
18\end{array}$ & $\begin{array}{r}13.5 \\
12.0 \\
8.5 \\
12.1\end{array}$ & $\begin{array}{l}321 \\
250 \\
190 \\
330\end{array}$ \\
\hline 18 & $\begin{array}{l}\text { Primary hypertension } \\
\text { with complications }\end{array}$ & 37 & 4.7 & 960 \\
\hline $\begin{array}{l}26 \\
29 \\
30 \\
31 \\
32 \\
37\end{array}$ & $\begin{array}{l}\text { Malignant hypertension } \\
\text { Malignant hypertension } \\
\text { Malignant hypertension } \\
\text { Malignant hypertension } \\
\text { Malignant hypertension } \\
\text { Malignant hypertension }\end{array}$ & $\begin{array}{l}35 \\
71 \\
37 \\
45 \\
47 \\
78\end{array}$ & $\begin{array}{c}3.4 \\
5.3 \\
4.2 \\
4.3 \\
11.5 \dagger \\
9.2\end{array}$ & $\begin{array}{r}800 \\
860 \\
1,225 \\
2,180 \\
2,730 \\
10,000\end{array}$ \\
\hline
\end{tabular}

\footnotetext{
* Blood urea nitrogen.
$\dagger$ In this subject no radioactivity was released by enzyme hydrolysis of the urine collected on the second day after injection.
}

groups; the former ranging from 7.9 to 14.3 per cent; the latter, from 3.4 to 11.5 per cent. $\mathrm{Pa}$ tient 37 with a blood urea nitrogen of $78 \mathrm{mg}$ per $100 \mathrm{ml}$ had a secretory rate of $10,000 \mu \mathrm{g}$ per day, whereas Patient 29 with a blood urea nitrogen of $71 \mathrm{mg}$ per $100 \mathrm{ml}$ had a secretory rate of only 860 $\mu \mathrm{g}$ per day.

Of the patients in this group an effort was made only once to determine whether radioactivity was still being excreted after the first day. Patient 32 who excreted 11.5 per cent of the injected tritium on the first day (secretory rate $=2,730 \mu \mathrm{g}$ ) excreted no detectable radioactive metabolite on the second day. Thus, in this single study, at least, the observed high secretion rate appears to be unrelated to renal failure, because all of the radioactive metabolite destined for excretion appeared within the first 24 hours. While this requirement has not actually been demonstrated in the other subjects with renal failure, the fact that these subjects often excreted about as much isotope as did the normal controls, and the fact that high secretion rates did not always correlate with renal failure, tend to indicate that the observed increases in aldosterone secretion are not related to kidney disease but rather to a truly increased adrenal production.
Because an abnormally prolonged excretion of isotopically labeled metabolite in renal disease would produce artificially high estimates of the 24 hour secretory rate, another group of ten patients has been studied in which the urinary collection periods were extended to two or three days, and the specific activity of labeled metabolite was determined for each of the days of collection. These data are summarized in Table III and in Figure 2. Included in this group are three pregnant women in the third trimester, four patients with renal diseases other than malignant hypertension, one patient with uncomplicated hypertension (normal renal function) and three patients with malignant hypertension.

Since accurate quantitation of the amount of radioactivity in the metabolite is difficult, its specific activity, derived from the ratio of $\mathrm{H}^{3}$ to $\mathrm{C}^{14}$ in the triacetate of the metabolite, was determined instead. If the major portion of labeled metabolite is excreted in the first 24 hours, the $\mathrm{H}^{3} / \mathrm{C}^{14}$ ratio for the first day should be much higher than that for subsequent days. The average secretion per day over a two or three day period was calculated from the average $\mathrm{H}^{3} / \mathrm{C}^{14}$ ratio over the given period. When the average secretion rate was the same as the secretion rate determined for 
TABLE III

The effect of delayed excretion of labeled tetrahydroaldosterone on the estimation of the aldosterone secretory rate

\begin{tabular}{|c|c|c|c|c|c|c|c|c|c|}
\hline \multirow{3}{*}{$\begin{array}{l}\text { Patient and } \\
\text { diagnosis }\end{array}$} & \multirow{2}{*}{\multicolumn{2}{|c|}{ Renal status }} & \multicolumn{3}{|c|}{$\begin{array}{l}\text { Estimated secretory* } \\
\text { rate }(\mu \mathrm{g} / \text { day }) .\end{array}$} & \multirow{3}{*}{$\begin{array}{l}\mathrm{H}^{3} / \mathrm{C}^{14} \dagger \text { of } \\
\text { aldosterone } \\
\text { tetrahydro } \\
\text { metabolite }\end{array}$} & \multicolumn{2}{|c|}{ Counts per minute } & \multirow{3}{*}{$\begin{array}{l}\text { Per cent } \\
\text { of injected } \\
\text { dose }\end{array}$} \\
\hline & & & \multirow[b]{2}{*}{ Days } & \multirow{2}{*}{ S. R. } & \multirow{2}{*}{$\begin{array}{l}\text { Per cent of } \\
\text { labeled } \\
\text { metabolite } \\
\text { accounted } \\
\text { for }\end{array}$} & & \multirow{2}{*}{$\begin{array}{l}\text { Released by } \\
\text { glucuronidase }\end{array}$} & \multirow{2}{*}{$\begin{array}{l}\text { In eluate } \\
\text { of first } \\
\text { chromato- } \\
\text { gram }\end{array}$} & \\
\hline & BUN & Proteinuria & & & & & & & \\
\hline $1 \quad(a)$ & 18 & 0 & 1 & 310 & 93.6 & 54.7 & 104,000 & 95,000 & 12 \\
\hline Lav. & & & 2 & 290 & & 1.7 & 21,000 & 1,500 & 0.16 \\
\hline Primary & & & 3 & & & & 6,000 & 1,100 & 0.14 \\
\hline hypertension $(b)$ & 18 & 0 & 1 & 270 & 96.3 & 86.7 & 104,000 & 95,000 & 8.9 \\
\hline & & & $\begin{array}{l}2 \\
3\end{array}$ & 260 & & 4.3 & $\begin{array}{r}44,000 \\
8500\end{array}$ & 7,000 & 0.65 \\
\hline & & & & & & & & & \\
\hline $\begin{array}{l}2 \\
\text { Ver }\end{array}$ & 12 & + & 1 & 750 & & 9.5 & 50,000 & 35,000 & 12.5 \\
\hline Pregnancy & & & $\begin{array}{l}2 \\
3\end{array}$ & & & 0.3 & 2,500 & 3,000 & 1.0 \\
\hline & 7 & ++ & 1 & 840 & 84.6 & 9.4 & 41,000 & 69,000 & 24.6 \\
\hline $\begin{array}{l}\text { Thom. } \\
\text { Pregnancy }\end{array}$ & & & 2 & 710 & & 1.6 & 7,700 & 23,000 & 8.2 \\
\hline $\begin{array}{l}4 \\
\text { Vict. }\end{array}$ & 11 & $+++t$ & $\begin{array}{l}1 \\
2\end{array}$ & 1,200 & & 6.6 & $\begin{array}{r}30,000 \\
1,500\end{array}$ & 43,000 & 15.3 \\
\hline Pregnancy & & & & & & & & & \\
\hline \multirow{6}{*}{$\begin{array}{l}5 \\
\text { Du. } \\
\text { Nephrosis }\end{array}$} & 14 & $++t+$ & 1 & 380 & 89.5 & 22.8 & 33,000 & 22,000 & 5.5 \\
\hline & & & 2 & 350 & 97.2 & 1.0 & 9,000 & 1,000 & 0.25 \\
\hline & & & 3 & 340 & & 0.36 & 5,000 & 500 & \\
\hline & 14 & $+++t$ & 1 & 310 & 95.2 & 73.4 & 158,000 & 66,500 & 6.3 \\
\hline & & & 2 & 295 & & 3.7 & 37,000 & 3,000 & 0.3 \\
\hline & & & 3 & 295 & & 0.084 & 14,000 & 750 & 0.1 \\
\hline \multirow{4}{*}{$\begin{array}{l}6 \\
\text { Tayl. } \\
\text { Malignant } \\
\text { hypertension }(b)\end{array}$} & 35 & + & 1 & 925 & 89.8 & 9.7 & 43,000 & 16,000 & 4.1 \\
\hline & & & 2 & 830 & & 1.1 & 8,000 & 1,500 & 0.4 \\
\hline & 45 & + & 1 & 510 & 87.3 & 16.8 & 16,000 & 10,000 & 2.5 \\
\hline & & & 2 & 445 & & 2.4 & 5,500 & 4,500 & 1.1 \\
\hline \multirow{3}{*}{$\begin{array}{l}7 \\
\text { Youn. } \\
\text { Diabetic } \\
\text { nephropathy }\end{array}$} & 49 & ++ & 1 & 210 & 88.1 & 42 & & 31,000 & 8.2 \\
\hline & & & 2 & 185 & & 6.2 & & 5,000 & 1.4 \\
\hline & & & 3 & & & & 64,000 & 1,200 & 0.3 \\
\hline \multirow{5}{*}{$\begin{array}{l}8 \\
\text { Vel. } \\
\text { Malignant } \\
\text { hypertension }(b)\end{array}$} & 55 & +++ & 1 & 740 & 77.0 & 11.6 & 23,500 & 18,000 & 4.6 \\
\hline & & & 2 & 595 & 95.8 & 2.8 & 6,500 & 3,600 & 0.9 \\
\hline & & & 3 & 570 & & 0.5 & 1,000 & 1,000 & \\
\hline & 67 & +++ & 1 & 665 & 73.7 & 13.5 & 30,000 & 13,000 & 3.3 \\
\hline & & & $\begin{array}{l}2 \\
3\end{array}$ & 490 & & 4.7 & $\begin{array}{r}15,000 \\
5,000\end{array}$ & 5,000 & 1.3 \\
\hline \multirow{2}{*}{$\begin{array}{l}9 \\
\text { Kirt. } \\
\text { Nephrosclerosis }\end{array}$} & 89 & +++ & 1 & 200 & & 43.2 & 23,000 & 10,000 & 2.6 \\
\hline & & & 2 & & & & 13,000 & 2,200 & 0.6 \\
\hline \multirow{5}{*}{$\begin{array}{l}10 \\
\text { Chris. } \\
\text { Sodium-losing } \\
\text { nephritis }(b)\end{array}$} & 86 & 0 & 1 & 1,000 & & 9.7 & 26,000 & 11,000 & 2.6 \\
\hline & & & 2 & & & & 14,000 & 6,200 & 1.5 \\
\hline & & & 3 & & & 0.14 & 11,000 & 1,500 & 0.4 \\
\hline & 104 & 0 & 1 & 1,320 & 73.5 & 18.0 & 77,000 & 60,000 & 5.5 \\
\hline & & & 2 & 970 & & 6.4 & 25,000 & 20,000 & 1.8 \\
\hline \multirow{3}{*}{$\begin{array}{l}11 \\
\text { Dunc. } \\
\text { Malignant } \\
\text { hypertension }\end{array}$} & 185 & ++++ & 1 & 14,600 & & 0.59 & 8,000 & 4,000 & 1.0 \\
\hline & & & 2 & 7,500 & & 0.54 & 10,000 & 3,000 & 0.75 \\
\hline & & & 3 & 6,000 & & 0.30 & 4,000 & 2,000 & 0.50 \\
\hline
\end{tabular}

* The secretion rate (S.R.) for Days 2 and 3 is calculated from $\frac{\mathrm{H}^{3} / \mathrm{C}^{14} \text { Day } 1+\mathrm{H}^{3} / \mathrm{C}^{14} \text { Day } 2+\cdots \mathrm{H}^{3} / \mathrm{C}^{14} \text { Day } \mathrm{n}}{\mathrm{n}} ;$ and $\frac{(\mathrm{S} . \mathrm{R} .) \mathrm{n}}{\mathrm{n}}=\mathrm{S} . \mathrm{R} . / \mathrm{day}$.

Per cent of labeled metabolite accounted for is the per cent of completeness of excretion of the labeled metabolite of the 


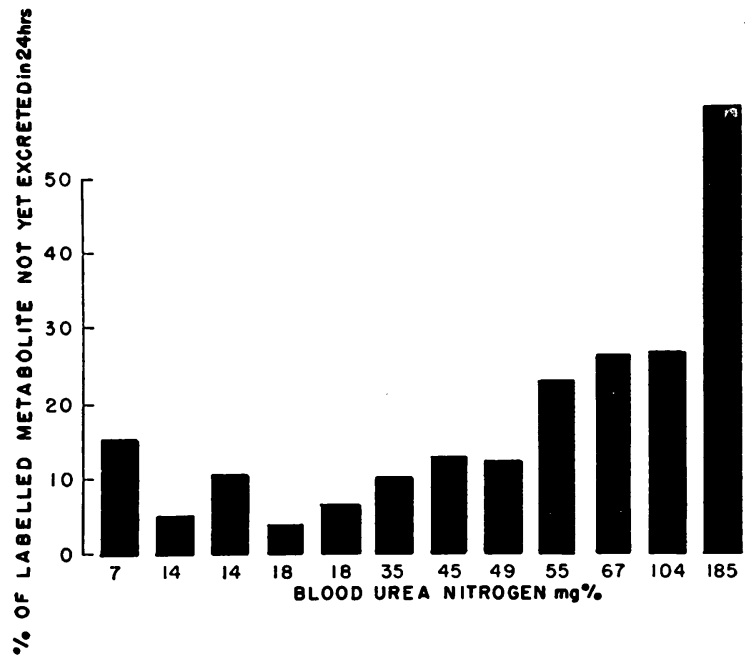

Fig. 2. Relation of UREa REtention to REtention of aldosterone metabolite after 24 Hours. Aldosterone secretion rates which are based on the collection of a single 24 hour urine collection are artificially high because of incomplete excretion of labeled tetrahydroaldosterone. The per cent of labeled metabolite destined for excretion which had not yet been excreted in the first 24 hours was determined in each instance by serial urine collections which allowed more complete excretion of the labeled metabolite. The blood urea nitrogen values are presented below each of the patients studied. It can be seen that in patients without urea retention the error caused by delayed excretion is small because about 90 per cent of the labeled metabolite has been excreted. The excretion rate of labeled metabolite appears to be inversely related to the level of the blood urea nitrogen. However, delayed excretion of metabolite does not appear to modify the 24 hour secretory rate determination to a significantly greater degree until urea retention is relatively advanced. The value obtained in the patient with a blood urea nitrogen of $185 \mathrm{mg}$ per $100 \mathrm{ml}$ was considered invalid since no evidence for complete excretion of labeled metabolite could be obtained (see text).

the first day, all of the labeled metabolite was excreted during the first 24 hours. As a general principle, the excretion of labeled metabolite can be assumed to be complete when the estimate of the average daily secretion rate is no longer modified by inclusion of subsequent urine collections in the determination. By dividing the average secretory rate (S.R. obtained over $\mathrm{n}$ days) by the S.R. based only upon the first 24 hour collection, the fraction of the total accounted for metabolite which was excreted within the first day can be estimated. This fraction $\times 100=$ the percentage of labeled metabolite accounted for in the first day, and these percentages are given in column 6 of Table III. When the S.R. for Day 1 is multiplied by this fraction, a value for the S.R. is obtained which has been corrected for delayed isotope excretion. Further, $100-\frac{\text { S.R. Day } n}{\text { S.R. Day } 1 i}$ yields the percentage of counts not yet excreted after the first 24 hours, and this latter value, therefore, also represents the percentage by which the first 24 hour collection is artificially high because of incomplete excretion (Figure 2).

Normally, about 90 per cent of the labeled metabolite is excreted in the first 24 hours. One might then expect that measurements of secretion rates in normal subjects might be falsely high by about 10 per cent. This expectation has actually been demonstrated in three subjects with normal blood urea nitrogen values (Table III, Patients 1,3 and 5). In five different serial studies of these three subjects, determination of the secretion rate based on two or three day urine collections indicates that estimates based only on the first 24 hour collections were artificially high by from 3.7 to 15.4 per cent (96.3 to 84.6 per cent of labeled metabolite was excreted in the first 24 hours).

In the application of this method to the study of diseases associated with renal insufficiency, such as malignant hypertension, the critical question is whether delayed excretion of the isotope causes overestimation of the 24 hour secretory rate beyond the 10 per cent error normally encountered. The data presented in Table III indicate that renal insufficiency can, in fact, lead to secretion rate values which should be reduced by as much as

first 24 hours $=\frac{\text { Avg. S.R. } n \text { days }}{\text { S.R. Day } 1} \times 100 . \quad \frac{\text { This value }}{100}$ multiplied by the observed secretory rate of the first 24 ihours $=$ the secretory value corrected for delayed excretion (C.S.R.).

$\dagger$ The $\mathrm{H}^{3} / \mathrm{C}^{14}$ ratio is presented. The percentage change from Day 1 to Day 2 or to Day 3 may not necessarily correspond with the percentage change in the secretory rate because the specific activity of the $\mathrm{C}^{14}$-acetic anhydride used for acetylation varied slightly in different batches.

‡ Counts per minute not corrected for quenching or promotion effects due to pigments in urinary extracts. The per cent of injected dose $=\frac{\text { no. of counts in metabolite zone of first chromat. }}{\text { no. of counts injected }} \times 100$. 
26.5 per cent (or, more properly, by the 16.5 per cent value in excess of the normal error). However, in most instances, the error is less. The 26.5 per cent figure was obtained in a patient with a blood urea nitrogen of $104 \mathrm{mg}$ per $100 \mathrm{ml}$ (Patient 10). Thus, the rate of excretion of the labeled metabolite by two subjects with overt renal insufficiency (Patients 6 and 7) did not differ significantly from patients with normal renal function. Of special interest is the finding that in two patients with malignant hypertension and azotemia (Patients 6 and 8), both tested twice, the percentages of labeled metabolite excreted in the first day were $89.8,87.3,77$ and 74 per cent.

One comatose patient with malignant hypertension and terminal uremia, who died the day after the last collection, has been included. This patient was obviously moribund. Unlike all others, the specific activity of the metabolite did not fall between the first and second days and fell by only 50 per cent in three days. The minimum estimated secretory rate was 6,000 , but this result is obviously invalid because no evidence for completeness of excretion of metabolite could be obtained before death of the patient. The number of counts excreted was small and constituted a trace of the injected dose. In contrast, in the one patient of the present series of malignant hypertensive subjects with a similarly high estimated secretory rate of $10,000 \mu \mathrm{g}$ (Patient 37. Table II) both the amount and the percentage of labeled metabolite excreted were similar to that of normal subjects and were considerably higher than those observed in Patient 11 of Table III. The possible error associated with this estimated $10,000 \mu \mathrm{g}$ production value was not determined, but from the experience summarized in Table III it seems likely that the corrected value would be considerably elevated above the normal range.

The experience summarized in Table III and in Figure 2 illustrates that the renal excretion of labeled tetrahydroaldosterone is inversely related to the excretion of urea. The data indicate that a secretion rate value in patients with azotemia may need to be corrected by as much as about 30 per cent. The data suggest that a correction factor based on the degree of azotemia should be applied to each of the secretion rates given in Table I in order to obtain a more accurate secretory rate value. However, it appears from re- examination of Table $I$ that even if a correction error of about 30 or even 40 per cent is applied to the malignant hypertensive patients studied, most of the abnormally high values remain above the normal limits. This finding, combined with the demonstration of hypersecretion in a number of the patients who did not exhibit nitrogen retention. suggests that the high values observed in this condition are not merely the result of delayed renal excretion of the metabolite.

Evidences for hypersecretion of other adrenal cortical hormones. Four of the patients reported in the present study were tested for their glucocorticoid response to an ACTH infusion. Patient 11 exhibited a rise in plasma 17-hydroxycorticoids (Porter-Silber method) from 31.2 to $51.6 \mu \mathrm{g}$ per $100 \mathrm{ml}$ after an ACTH infusion. Patient 15 responded by an increase in plasma hydroxycorticoids from 17.6 to $41.5 \mu \mathrm{g}$ per $100 \mathrm{ml}$. (This test was done after one adrenal had been removed.) Patient 23 exhibited a rise in plasma 17-hydroxycorticoids of from 35.7 to $58.0 \mu \mathrm{g}$ per $100 \mathrm{ml}$. These values are all considered to be within the upper limit of normal. Patient 27 has been previously reported in detail by Hilton, Westermann, Bergen and Crampton (15), and exhibited an abnormal response to the infusion of ACTH. This patient is the only patient in the series in whom hyper-responsiveness to ACTH was clearly present. In ten other patients of the present series the urinary 17-hydroxycorticosteroids and 17-ketogenic steroids were measured, and all of these values were within normal limits.

Correlation of findings with morphological changes in the adrenal tissue. In seven of the patients with malignant hypertension reported in this study, complete postmortem examination has been made. No tumor was found in the adrenals of any of these patients, but in four of the seven the adrenal glands were significantly above the upper limits of normal in weight. In all seven subjects the glands exhibited areas of focal hyperplasia and nodularity, especially in the region of the glomerulosa zone. In addition, there was focal increase in cellular activity and increased lipid deposits in focal cellular areas. Pathological findings in these cases, as well as in two other surgical specimens, will be the subject of a separate report (16).

Effect of various pharmacological agents. The 
effect of various antihypertensive drugs on the secretion rate of aldosterone is unknown. Certain of the patients (10 of 33) included in this series were under treatment with various hypotensive agents, and this has been recorded in Table I. From the results obtained, these agents do not appear to have had any consistent or specific effect on the secretion rate of aldosterone.

\section{DISCUSSION}

Estimation of the adrenal production rate by isotope dilution as carried out in the present study possesses a number of inherent advantages over the previously employed methods which have measured the small fraction of hormone excreted unchanged in the urine. However, it should be recognized that while the measurement of adrenal secretory rate would seem to be a more precise and reliable index of aldosterone activity, it too, may not always be an accurate reflection of the effective concentration of active hormone in the blood. Possibly, blood level measurements may provide additional information in this regard, and ultimately may even be necessary to assure proper interpretation of secretion rate studies.

The data presented suggest that a well defined biochemical difference exists between a group of patients classified as benign essential hypertension and those who manifest the clinical picture of advanced or of malignant hypertensive disease. Marked increases in the secretion rate of aldosterone were found in all but one of the patients with malignant hypertension and in three of eight patients classified as "advanced" hypertension. These increased values were observed in the presence of normal sodium intakes. In contrast, all of the patients with primary hypertension secreted normal amounts of aldosterone.

Thus, malignant hypertension represents another syndrome which is associated with increased secretion of aldosterone. While this clinical state resembles the disease produced in animals given excess mineralocorticoid, it clearly differs from the clinical picture of primary aldosteronism in that evidences of vasculitis are characteristically absent in the latter condition.

The frequent occurrence of hypokalemic alkalosis as manifested by either an elevated plasma bicarbonate and/or a reduced plasma potassium concentration in patients with advanced or with malignant hypertension appears as a somewhat unexpected finding. This tendency to alkalosis may be taken as supportive evidence of increased aldosterone secretion. The alkalosis may have additional significance since it was found to occur at times in the presence of renal failure where retention of fixed anions ordinarily tends to lower the plasma bicarbonate level and thus could mask the typical plasma abnormalities of aldosteronism.

In the patients reported here hypersecretion of aldosterone was often found in association with demonstrable renal insufficiency. One cannot deny that sodium-losing renal disease could lead to secondary hypersecretion of aldosterone in patients with advancing hypertensive disease. However, as pointed out above, the data obtained thus far do not tend to suggest the operation of such a mechanism. (Most of the patients conserved sodium normally.) Further study of patients with other forms of renal disease may be necessary to determine a possible relationship between aldosterone secretion and renal insufficiency. It should be restated here that the technique employed for estimation of adrenal secretion may be affected by renal insufficiency, but the error caused by delayed excretion has not been of sufficient magnitude to invalidate the results.

In general, the hypersecretion of aldosterone was more impressive in the seriously ill patients (10 of the 15 patients with malignant hypertension are now deceased). However, whether the aldosterone hypersecretion is a cause or a result of the severe disease is not clear. Hypersecretion of aldosterone has not been noted in association with various other severe illnesses (17), but here too, further studies are necessary, especially in patients with other forms of arteritis.

Prior to the present study, the association of potassium depletion and alkalosis with severe hypertension has been noted. Wyngaarden, Keitel and Isselbacher (18) reported the case of a 46 year old man with malignant hypertension and severe alkalosis whose adrenal glands were grossly normal at postmortem. Two other cases of potassium depletion associated with malignant hypertension and high aldosterone excretion have been reported $(19,20)$. In both, the authors considered that the observed aldosteronism might have been secondary to renal damage. Both of these 
patients succumbed without being helped by bilateral adrenalectomy, and here too, the adrenal glands were not grossly abnormal.

About 35 cases of primary aldosteronism have now been reported (17). About 28 of these have been shown to be associated with an adrenal adenoma, and two others were associated with adrenal carcinoma $(21,22)$. Hypertension of varying degree was present in all of the cases, but in only one of the cases associated with an adenoma was the hypertension malignant (23). This patient died without operation. In marked contrast, and of special interest in relation to the present study, is the fact that in five of the six reported cases $(15,24-28)$ of primary aldosteronism associated with bilateral adrenal cortical hyperplasia, the syndrome of malignant hypertension with papilledema was present. In all but one of these six patients subtotal adrenalectomy was carried out and was followed by improvement. The fact that the syndrome of malignant hypertension was so often found in these patients labeled "primary aldosteronism due to bilateral adrenal hyperplasia." illustrates again a fundamental difficulty in properly classifying these diseases. Obviously, these reported cases might well have been more appropriately classified as examples of "malignant hypertension" rather than of "primary aldosteronism."

The finding of an adrenal adenoma at least suggests a primary adrenal disease. On the other hand, the occurrence of bilateral adrenal hyperplasia is in keeping with secondary rather than with primary adrenal disease. In other words, the two diseases may be of entirely different origin. Also, they appear to be associated with different clinical pictures-bilateral adrenal hyperfunction being characteristically associated with malignant hypertension. However, as yet, no biochemical differences are apparent which might aid one in distinguishing the disease state of bilateral hyperplasia from that of an adrenal adenoma. Four of the cases of bilateral hyperplasia occurred at a young age (ages 9, 10, 13 and 17) and one other case (15) exhibited an abnormal glucocorticoid response to ACTH. One of our patients (no. 20) resembles the patient reported by Holten and Petersen (25) in that unilateral adrenalectomy in both was followed by a fall in aldosterone and striking clinical improvement. In both pa- tients the excised adrenal gland was histologically unremarkable. However, it is also possible that aldosterone hypersecretion remits spontaneously, and one of our patients (no. 34), a seven year old girl with malignant hypertension, has improved considerably on a medical regimen.

It is difficult to determine whether the clinical picture of malignant hypertension is caused by the excessive secretion of aldosterone or, alternatively, whether the hypersecretion is in some way a secondary reaction to the diseased state. That hypersecretion is a cause of the syndrome is suggested by the fact that the vascular lesions of malignant hypertension resemble those produced in animals given desoxycorticosterone (1). Moreover, the excessive production of aldosterone in these patients appears to be independent of the dietary sodium intake. On the other hand, certain observations suggest the contrary idea, that the hypersecretion is secondary to the underlying hypertensive disease. Thus, it is noteworthy that hypersecretion is absent in uncomplicated hypertension and becomes more and more prominent in association with development of renal and vascular complications. Secondly, the fact that the clinical picture is not the same as that of primary aldosteronism due to an adenoma suggests that pre-existing vascular disease is necessary for aldosterone hypersecretion to be associated with the malignant syndrome. This concept has support in animal studies wherein production of renal damage or a unilateral nephrectomy facilitates the production of the state of malignant hypertension by steroid administration.

In summary, the data appear to indicate that aldosterone hypersecretion does not participate in the pathogenesis of primary hypertensive disease. However, hypersecretion of aldosterone, perhaps superimposed on various hypertensive states, cannot be excluded as a causal factor in the development of the malignant syndrome. Viewed in this light, aldosterone hypersecretion may follow the hypertensive process but may possibly precede the syndrome of malignant hypertension. The nature of this stimulus to hypersecretion is unknown, but might be related to renal damage, because, regardless of the nature of the underlying hypertensive process, renal vascular damage is a most consistent finding in the malignant syndrome. 
If aldosterone is important in the pathogenesis of malignant hypertension, one might ask whether beneficial effects are to be expected from bilateral adrenalectomy. Unfortunately, this question cannot be categorically answered since results of adrenalectomy have been variable, and since many patients with malignant hypertension have been excluded from surgery because of attendant renal insufficiency. One patient in our series (no. 25) was subjected to bilateral adrenalectomy, but following the second operation terminal uremia developed. Two similar experiences have been reported $(19,20)$. It is possible that a more satisfactory answer can be obtained when patients are operated on earlier in the malignant phase. However, in this regard it should be remembered that in animals, after a certain stage, hypertension progresses when desoxycorticosterone is no longer administered ("metacorticoid" hypertension) (29). Another, perhaps more promising, approach to the problem involves the administration of aldosterone inhibitors. These studies are currently under way in our laboratory.

The findings reported here perhaps confirm in part the work of Genest and associates (8) who reported increased urinary excretion of aldosterone in some patients with malignant hypertension. However, these workers also found increased aldosterone excretion in milder forms of hypertension, and this latter finding is at variance with our data.

\section{SUMMARY}

A technique of isotope dilution which involves the injection of a trace dose of tritiated aldosterone and the determination of the specific activity of labeled tetrahydroaldosterone in the subsequent 24 hour urine has been applied to the study of patients with hypertensive vascular disease. The technique obviates a difficulty inherent in previous studies which have been based on measurement of the small fraction of aldosterone excreted unchanged in urine.

In eight patients with benign essential hypertension, the adrenal secretion rate of aldosterone was found to be within the normal limits (180 to $330 \mu \mathrm{g}$ per day). The values were similar to those obtained in eight normal subjects maintained on comparable normal intakes of sodium ion.
The secretion rate of aldosterone was also within the normal range in two patients with hypertension associated with unilateral renal disease.

Five patients with proven primary aldosteronism due to adrenal adenoma (Conn's syndrome) exhibited significantly increased secretory rates of from 510 to $1,690 \mu \mathrm{g}$ per day.

In three of eight advanced hypertensive patients studied, and in all but one of 15 patients with malignant hypertension, the adrenal secretion rate of aldosterone was significantly elevated. The abnormal values ranged upwards from $510 \mu \mathrm{g}$ per day in these patients. The patients with malignant hypertension resembled those with primary aldosteronism in that the hypersecretion was not associated with grossly reduced urinary sodium excretion. With unexpected frequency, the patients with malignant hypertension also exhibited a tendency to hypokalemia and/or an elevated plasma bicarbonate level, even in the presence of renal failure.

Delayed excretion of the labeled metabolite can be related to the degree of nitrogen retention present and may lead to artificially high estimates of the 24 hour secretion rate. Nevertheless, in the experience to date the error produced by excretory failure does not appear to be of sufficient magnitude to invalidate results based on 24-hour urine collections.

The results provide no indication that aldosterone hypersecretion participates in the pathogenesis of primary (benign) hypertension.

The data obtained on the patients studied establish that the syndrome of malignant hypertension is usually associated with hypersecretion of aldosterone. In addition to the differences in the clinical picture between patients with malignant hypertension and those with Conn's syndrome, the hypersecretion of aldosterone may differ in its origin. In malignant hypertension it seems to be due to bilateral adrenal hyperfunction rather than to an adrenal adenoma.

Hypersecretion of aldosterone in the syndrome of malignant hypertension may prove to be a secondary or concomitant phenomenon. However, the results presented here make it reasonable to consider the possibility that hypersecretion of aldosterone plays a causal role in malignant hypertension. 


\section{REFERENCES}

1. Selye, H., Hall, C. E., and Rowley, E. M. Malignant hypertension produced by treatment with desoxycorticosterone acetate and sodium chloride. Canad. med. Ass. J. 1943, 49, 88.

2. Perera, G. A., Knowlton, A. I., Lowell, A., and Loeb, R. F. Effect of desoxycorticosterone acetate on the blood pressure of man. J. Amer. med Ass. $1944,125,1030$.

3. Knowlton, A. I., Loeb, E. N., Stoerk, H. C., and Seegal, B. C. Development of hypertension and nephritis in normal and adrenalectomized rats treated with cortisone. Proc. Soc. exp. Biol. (N. Y.) 1949, 72, 722.

4. Simpson, S. A., Tait, J. F., Wettstein, A., Neher, R., Von Euw, J., and Reichstein, T. Isolieurung eines neuen kristallisierten Hormons aus Nebennieren mit besonders hoher Wirksamkeit auf den Mineralstoff-Wechsel. Experientia (Basel) 1953, 9, 333.

5. Conn, J. W. Primary aldosteronism, a new clinical syndrome. J. Lab. clin. Med. 1955, 45, 3.

6. Ferrebee, J. W., Parker, D., Carnes, W. H., Gerity, M. K., Atchley, D. W., and Loeb, R. F. Certain effects of desoxycorticosterone; the development of "diabetes insipidus" and the replacement of muscle potassium by sodium in normal dogs. Amer. J. Physiol. 1941, 135, 230.

7. Tobian, L., Jr., and Binion, J. I. Tissue cations and water in arterial hypertension. Circulation 1952, 5, 754.

8. Genest, J., Koiw, E., Nowaczynski, W., and Leboeuf, G. Further studies on urinary aldosterone in human arterial hypertension. Proc. Soc. exp. Biol. N. Y. 1958, 97, 676.

9. Ulick, S., Laragh, J. H., and Lieberman, S. The isolation of a urinary metabolite of aldosterone and its use to measure the rate of secretion of aldosterone by the adrenal cortex of man. Trans. Ass. Amer. Phycns 1958, 71, 225.

10. Laragh, J. H. The effect of potassium chloride on hyponatremia. J. clin. Invest. 1954, 33, 807.

11. Wilzbach, K. E. Tritium-labeling by exposure of organic compounds to tritium gas. J. Amer. chem. Soc. 1957, 79, 1013.

12. Okita, G. I., Kabara, J. J., Richardson, F., and LeRoy, G. V. Assaying compounds containing $\mathrm{H}^{3}$ and $C^{14}$. Nucleonics 1957, 15, 111.

13. Stanbury, S. W., Gowenlock, A. H., and Mahler, R. F. Interrelationships of potassium deficiency and renal disease in Aldosterone. An International Symposium, A. F. Muller and C. M. O'Connor,
Eds. Boston, Little, Brown \& Co., 1958, pp. 155166.

14. Rifkin, H., Solomon, S., and Lieberman, S. Role of the adrenal cortex in diabetic retinopathy and nephropathy. Diabetes 1958, 7, 9.

15. Hilton, J G., Westermann, C. D., Bergen, S. S., and Crampton, R. S. Syndrome of mineralocorticoid excess due to bilateral adrenocortical hyperplasia. New Engl. J. Med. 1959, 260, 202.

16. Lucas, F., and Laragh, J. H. To be published.

17. Laragh, J. H. Aldosterone in fluid and electrolyte disorders: Hyper and hypoaldosteronism. J. chron. Dis. 1960, 11, 292.

18. Wyngaarden, J. B., Keitel, H. G., and Isselbacher, K. J. Potassium depletion and alkalosis, their association with hypertension and renal insufficiency. New Engl. J. Med. 1954, 250, 597.

19. FitzGerald, M. G., Fourman, P., James, A. H., and Scarborough, H. Malignant hypertension, adrenal hyperplasia and depletion of potassium. Scot. Med. J. 1957, 2, 473.

20. Eales, L., and Linder, G. C. Potassium losing pyelonephritis and malignant hypertension: A case report with balance studies. Metabolism 1959, 8, 445.

21. Foye, L. V., Jr., and Feichtmeir, T. V. Adrenal cortical carcinoma producing solely mineralocorticoid effect. Amer. J. Med. 1955, 19, 966.

22. Brooks, R. V., McSwiney, R. R., Prunty, F. T., and Wood, F. J. Potassium deficiency of renal and adrenal origin. Amer. J. Med. 1957, 23, 391.

23. Flynn, P. Adrenal cortical tumour with fulminating hypertension. J. Irish med. Ass. 1956, 39, 77.

24. van Buchem, F. S. P., Doorenbos, H., and Elings, H. S. Primary aldosteronism due to adrenocortical hyperplasia. Lancet 1956, 2, 335.

25. Holten, C., and Petersen, V. P. Malignant hypertension with increased secretion of aldosterone and depletion of potassium. Lancet 1956, 2, 918.

26. Bartter, F. C., and Biglieri, E. G. Primary aldosteronism: Clinical Staff Conference at National Institutes of Health. Ann. intern. Med. 1958, 48, 647.

27. Kretchmer, N., Dickinson, A., and Karl, R. Aldosteronism in nine-year-old child (abstract). J. Dis. Child. 1957, 94, 452.

28. Mellinger, R., Therian, B., Kline, I. T., Ditzler, J., Smith, R., and Fine, G. Primary aldosteronism. Henry Ford Hosp. Bull. 1958, 6, 1.

29. Friedman, S. M., Friedman, C. L., and Nakashima, M. Sustained hypertension following the administration of desoxycorticosterone acetate. J. exp. Med. 1951, 93, 361. 